\title{
PELANGGARAN PRINSIP KERJA SAMA DAN KESANTUNAN BERBAHASA DALAM CUITAN TWITTER BERTEMA INTERNALIZED SEXISM 'INTERNALISASI SEKSISME': SUATU KAJIAN PRAGMATIK
}

\author{
Rima Rismaya \\ Fakultas Ilmu Budaya Universitas Padjadjaran \\ rima19002@mail.unpad.ac.id
}

\begin{abstract}
Abstrak
Penelitian ini bertujuan untuk mendeskripsikan bentuk pelanggaran prinsip kerja sama dan kesopanan berbahasa, serta kemungkinan penyebab munculnya pelanggaran-pelanggaran tersebut. Penelitian ini menggunakan metode penelitian deskriptif kualitatif dengan topik utama yaitu pelanggaran prinsip kerja sama dan kesantunan berbahasa yang terdapat dalam komentar terhadap cuitan Twitter bertema internalized sexism. Sumber data penelitian adalah komentar-komentar berbahasa Indonesia dalam cuitan akun @cunggun. Data penelitian ini dikumpulkan melalui metode simak dengan teknik tandai dan catat. Analisis data penelitian dilakukan dengan menggunakan metode analisis isi. Berdasarkan penelitian yang dilakukan, terdapat pelanggaran prinsip kerja sama yang dikelompokkan menjadi pelanggaran terhadap maksim kualitas, maksim kuantitas, maksim relevansi, dan maksim cara. Kemudian, pelanggaran prinsip kesantunan berbahasa terjadi pada pelanggaran maksim kebijaksanaan, maksim kemurahan, maksim penerimaan, maksim kerendahan hati, maksim kecocokan, dan maksim kesimpatian. Pelanggaran ini dilakukan sebagai bentuk kemarahan petutur atas cuitan penutur yang dianggap merendahkan sesama kaum wanita.
\end{abstract}

Kata kunci: pelanggaran; prinsip; maksim; Twitter.

\begin{abstract}
This research aims to describe the forms of violations of the principles of cooperation and language politeness, and the possible causes of these violations. This research used a qualitative descriptive research method with the main topic of violating the principles of cooperation and language politeness in comments onthemed Twitter tweets internalized sexism. The source of research data is Indonesian language comments in the @cunggun account. The research data were collected through the observation method with mark and note technique. The research data analysis was carried out using the content analysis method. Based on the research conducted, there are violations of the principle of cooperation which are grouped into violations of the maxim of quality, maxim of quantity, maxim of relevance, and maxim of method. Then, the violation of the principle of language politeness occurs in the violation of the maxim of wisdom, the maxim of mercy, the maxim of acceptance, the maxim of humility, the maxim of compatibility, and the maxim of sympathy. This violation was carried out as a form of anger by speakers over the tweets of speakers who were deemed demeaning to fellow women.
\end{abstract}

Keywords: violation; principles; maxims; Twitter.

\section{PENDAHULUAN}

Media sosial saat ini memiliki peranan penting dalam komunikasi masyarakat sehari-hari. Keterbatasan keadaan, misalnya jarak dan tempat, mengakibatkan masyarakat mengandalkan media sosial sebagai sarana berkomunikasi dengan orang lain. Salah satu media sosial yang umum digunakan 
oleh masyarakat Indonesia adalah Twitter. Pengguna mengunggah cuitan (tweet) yang dapat berisi foto, video, tautan, dan teks. Situasi kebahasaan media sosial nampaknya agak berbeda dengan situasi kebahasaan dalam komunikasi langsung tatap muka. Dalam komunikasi tatap muka, manusia juga mengandalkan ekspresi wajah dan gerak tubuh sebagai pendukung bahasa verbal yang ia ujarkan. Sayangnya, bahasa tubuh ini tidak bisa ditampakkan dalam komunikasi media sosial melalui tulisan. Beberapa media sosial memang mendukung adanya penggunaan emoticon untuk menyemarakkan situasi komunikasi. Namun, emoticon ini tetap tidak bisa berperan semaksimal bahasa tubuh. Hal inilah yang berkemungkinan untuk menimbulkan kesalahpahaman atas konteks dan makna tuturan seseorang.

Diperlukan adanya pemahaman bersama mengenai adanya kerja sama yang harus dijalankan dengan baik ketika komunikasi sedang berlangsung. Setiap individu yang terlibat dan berinteraksi dalam suatu situasi komunikasi, diharapkan agar senantiasa bekerja sama dan menjaga citra diri satu sama lain (Adani dkk., 2017: 82). Selain kerja sama, kesantunan berbahasa juga menjadi aspek penting dalam komunikasi. Kesantunan berbahasa dalam media sosial sering terabaikan. Leech (2014) berpendapat bahwa orang-orang bisa berperilaku tidak sopan ketika mereka tidak melihat adanya alasan untuk bersikap sopan. Berdasarkan pernyataan Leech tersebut, orang-orang yang berkomunikasi melalui media sosial sering kali merasa dirinya superior karena identitasnya bisa saja tersamarkan. Mereka tidak menemukan alasan untuk bersikap sopan karena adanya anggapan bahwa media sosial merupakan tempat yang bebas untuk berpendapat mengenai apapun. Hal ini barangkali benar, tetapi aspek penggunaan bahasa yang santun juga patut untuk dipertimbangkan. Bahasa tidak santun yang diujarkan oleh seorang penutur bisa mengancam wajah atau citra diri petutur atau mitra tuturnya (Pramujiono, 2015: 45). Selain itu, berbahasa tidak hanya sekedar menyampaikan ide dan perasaan, tetapi juga bagaimana menggunakan dan memilih kata-kata yang tepat kepada petutur dalam situasi dan kondisi yang tepat pula (Budiawati, 2017: 558). Kebebasan penggunaan bahasa dalam media sosial berkemungkinan menyebabkan orang berbahasa sesuka hati tanpa memikirkan kemungkinan petuturnya merasa dirugikan.

Penelitian mengenai prinsip kerja sama dalam komunikasi pernah dilakukan oleh Triana (2012), yaitu mengenai prinsip kerja sama dalam film kartun Avatar. Penelitian deskriptif dengan teknik analisis isi ini menghasilkan temuan bahwa terdapat empat tipe prinsip kerja sama dalam film kartun Avatar yang terbagi ke dalam maksim kuantitas, maksim kualitas, maksim relevansi, dan maksim cara. Prinsip kerja sama tidak bisa selamanya terpenuhi dalam beragam tuturan. Ada pula situasi tuturan yang memungkinkan terjadinya pelanggaran prinsip kerja sama. Penelitian mengenai hal ini pernah dilakukan oleh Sulistyowati (2012). Fokus utama penelitian ini adalah mengkaji pelanggaran prinsip kerja sama dan implikatur percakapan dalam film Petualangan Sherina karya Riri Riza. Berdasarkan penelitian pragmatik ini, ditemukan adanya pelanggaran terhadap maksim kuantitas, maksim kualitas, dan maksim cara. Namun, penelitian mengenai pelanggaran prinsip kerja sama yang menggunakan sumber data dari cuitan Twitter bertema internalized sexism belum pernah dilakukan sebelumnya. 
Selain prinsip kerja sama, penelitian mengenai prinsip kesantunan berbahasa juga pernah dilakukan. Penelitian kesantunan berbahasa telah dilakukan oleh Halawa dkk. (2019) mengenai kesantunan bertutur dalam melarang dan mengkritik berdasarkan etnis yang meliputi: (1) mitra lebih tua atau lebih tinggi kedudukannya dan belum akrab; (2) mitra tutur sama besar atau sama kedudukannya dan belum akrab; (3) mitra tutur lebih muda atau lebih rendah kedudukannya dan belum akrab; (4) mitra tutur orang yang disegani; (5) mitra tutur lebih tua atau tinggi kedudukannya dan sudah akrab; (6) mitra tutur sama besar atau sama kedudukannya dan sudah akrab; dan (7) mitra tutur lebih muda atau lebih rendah dan sudah akrab. Kemudian, penelitian mengenai pelanggaran kesantunan berbahasa telah dilakukan oleh Sari (2019), yaitu pelanggaran prinsip kesantunan berbahasa dalam acara Dua Arah Kompas TV.

Namun, belum ada penelitian mengenai pelanggaran prinsip kerja sama maupun kesantunan berbahasa yang memanfaatkan data penelitian bertema internalized sexism. Padahal, Isu mengenai internalized sexism sudah sejak lama hadir, baik dalam komunikasi langsung, maupun komunikasi dalam media sosial. Meskipun demikian, sebenarnya belum banyak orang yang mengetahui bahwa cuitan atau unggahan yang berusaha membuat diri pemilik akun media sosial tersebut berbeda dan lebih spesial dari yang lainnya tersebut disebut dengan internalized sexism atau internalisasi sexisme. Maka dari itu, penelitian pragmatik ini berbeda dengan penelitian-penelitian yang telah disebutkan tersebut. Selain mendeskripsikan pelanggaran prinsip kerja sama dan kesantunan berbahasa, penelitian ini juga mendeskripsikan kemungkinan penyebab munculnya beragam pelanggaran prinsip tersebut dalam cuitan bertema internalized sexism. Hal ini disebabkan karena banyak pengguna media sosial memberikan respons yang sama terhadap unggahan yang menurut mereka merupakan bentuk dari internalized sexism. Berdasarkan hal tersebut, diperlukan deskripsi mengenai penyebab munculnya pelanggaran prinsip kerja sama dan kesopanan berbahasa yang kebanyakan berupa kalimat-kalimat sinisme, ironi, maupun sarkasme terhadap pemilik unggahan bertema internalized sexism. Tujuan dilakukannya penelitian ini secara khusus adalah untuk mendeskripsikan (1) bentuk pelanggaran prinsip kerja sama dalam komentar terhadap cuitan Twitter bertema internalized sexism; (2) bentuk pelanggaran prinsip kesantunan berbahasa dalam komentar terhadap cuitan Twitter bertema internalized sexism; dan (3) kemungkinan penyebab adanya pelanggaran prinsip kerja sama dan kesantunan berbahasa dalam komentar terhadap cuitan Twitter bertema internalized sexism.

Penelitian mengenai pelanggaran prinsip kerja sama dan kesantunan berbahasa ini merupakan penelitian dalam ranah pragmatik. Pragmatik merupakan salah satu cabang ilmu bahasa yang mengkaji makna kontekstual yang disampaikan oleh penutur dan penafsiran tuturan tersebut oleh petutur, mitra tutur, rekan tutur, pendengar, atau pembacanya (Sekarsany dkk., 2020: 15). Secara sederhana, pragmatik mempelajari konteks dan situasi tutur yang dilakukan oleh penutur dan petutur serta pengaruhnya terhadap interpretasi makna oleh petutur. Bachari \& Juansah (2017) menyatakan bahwa sebuah kalimat yang dituturkan, pada kenyataannya selain mendeskripsikan suatu hal, juga melakukan tindakan tertentu sebagai penunjang deskripsi tersebut. Suatu tindakan hadir sebagai konsekuensi dari hal yang telah dituturkan sebelumnya. Penutur merupakan orang yang mengujarkan 
atau menuturkan suatu tuturan, sedangkan petutur adalah mitra atau rekan penutur ketika tuturannya diujarkan. Kalimat yang dituturkan dalam komunikasi ini sebenarnya tidak bisa diujarkan secara sembarangan. Agar peristiwa tuturan berjalan lancar dan maksud penutur bisa dipahami petuturnya, maka diperlukan kerja sama dalam komunikasi tersebut. Prinsip kerja sama yang umum dijadikan rujukan dalam pragmatik adalah prinsip kerja sama Grice.

Prinsip kerja sama Grice menerangkan bahwa penutur membuat kontribusi percakapan sesuai dengan yang diperlukan ketika tuturan itu terjadi, tujuan atau arah pertukaran pembicaraan dapat diterima kedua belah pihak (Kroeger, 2018). Terdapat empat maksim dalam prinsip kerja sama Grice sebagaimana dijelaskan oleh (Kroeger, 2018), antara lain (1) maksim kualitas (cobalah untuk membuat kontribusi Anda dengan benar; jangan katakan apa yang Anda yakini salah; dan jangan katakan bahwa Anda kekurangan bukti yang memadai); (2) maksim kuantitas (buat kontribusi Anda seinformatif yang diperlukan untuk tujuan pertukaran saat ini; dan jangan membuat kontribusi Anda lebih informatif daripada yang dibutuhkan); (3) maksim relevansi (buatlah tuturan anda relevan dengan situasi tuturan); (4) maksim cara (bersikaplah dengan jelas agar mudah dipahami; hindari ketidakjelasan ekspresi; hindari ambiguitas; bersikap singkat atau hindari kecurangan yang tidak perlu; dan bersikaplah teratur).

Selain prinsip kerja sama, tuturan juga mengandung prinsip lain yang disebut sebagai prinsip kesantunan atau kesopanan berbahasa. Kesantunan dalam arti luas adalah bentuk perilaku komunikasi yang ditemukan secara umum dalam bahasa dan budaya manusia (Leech, 2014). Kesantunan berbahasa sebagai bagian dari wujud pragmatik, mengkaji kesepakatan makna yang ditentukan oleh elemen wacana secara tradisional. Prinsip kesantunan atau kesopanan memiliki beberapa maksim. Sebuah tuturan akan menjadi sempurna apabila kesemua maksimnya dapat terpenuhi atau terlaksanakan dengan baik. Namun, dalam kehidupan sehari-hari, maksim ini sering kali dilanggar sehingga terjadi banyak penyimpangan.

Chaer (2010) menjelaskan bahwa ada beberapa faktor atau hal yang menyebabkan sebuah pertuturan itu menjadi tidak santun. Penyebab ketidaksantunan itu antara lain, (1) kritik secara langsung dengan kata-kata kasar, (2) dorongan rasa emosi penutur, (3) protektif terhadap pendapat, (4) sengaja menuduh lawan tutur, dan (5) sengaja memojokkan mitra tutur. Prinsip kesantunan menurut Leech (2014) dibagi menjadi enam, yaitu:

a. Maksim kebijaksanaan (tact maxim) yang menggariskan agar penutur meminimalkan kerugian orang lain atau memaksimalkan keuntungan orang lain. Kita diharuskan bersikap bijaksana untuk memilih kata yang tidak menyakiti orang lain dan memberikan atau menawarkan keuntungan pada lawan bicara. Dengan demikian, maksim kebijaksanaan adalah maksim yang mengutamakan keuntungan orang lain tanpa menyinggung atau menyakiti perasaan mitra tutur.

b. Maksim penerimaan (generosity maxim) yang dapat dilihat dalam balasan yang positif dan sesuai untuk tindak tutur permintaan, yang dapat menunjukkan ekuivalen intensif dari ya, seperti pada ya, tentu saja; pasti; tentu; dll. Namun, 
penolakan atas permintaan itu "tidak masuk akal" dan seringkali dilakukan secara tidak langsung atau bahkan tidak terucapkan

c. Maksim kemurahan adalah maksim yang dalam tuturannya sangat meminimalisasi kemungkinan terjadinya ketersinggungan yang dirasakan oleh petutur. Dalam maksim kemurahan, penutur sebisa mungkin memaksimalkan kerugian dan meminimalkan keuntungan untuk diri sendiri. Pada maksim ini pula penutur diharapkan mampu menggunakan kalimat sopan untuk menyatakan perasaannya.

d. Maksim kerendahan hati (modesty maxim). Penghinaan diri (jika tulus, bahkan jika dibesar-besarkan) sering dianggap sopan. Maksim kerendahan hati berusaha untuk mempertahankan hubungan baik antara penutur dengan petuturnya. Penutur dituntut agar mampu dan cerdas menempatkan dirinya dalam situasi tuturan. Seseorang yang tahu sopan santun biasanya tidak mengagungkan kemampuan yang dimilikinya. Mengagung-agungkan atau menonjolkan kemampuan, prestasi, atau harta milik, dan sebagainya, bila tidak dianggap perlu di depan lawan tutur identik dengan kesombongan yang tentu saja bertentangan dengan prinsip kesopanan yang harus ditaati. Dengan demikian, maksim kerendahan hati merupakan pernyataan yang tidak mengandung sifat kesombongan di dalamnya seperti membesar-besarkan hal yang dimiliki. Merendahkan orang lain karena merasa diri sendiri tinggi, dan sebagainya.

e. Maksim kecocokan (agreement maxim) yang meminimalkan adanya kesalahpahaman lewat pemanfaatan kekuasaan, umur, tingkat pendidikan, atau hal lainnya yang menunjukkan perbedaan posisi dan derajat antara penutur dan petutur. Adanya ketinggian hati, ketidakbijaksanaan, dan lain sebagainya, bisa menyebabnya ketidakharmonisan hubungan penutur dengan petutur.

f. Maksim kesimpatian (sympathy maxim). Kendala simpati atau keprihatinan emosional diperlukan untuk menjelaskan mengapa kita memberikan penghargaan untuk perasaan orang lain, misalnya dalam tindak tutur selamat atau belasungkawa (Leech, 2014). Hal tersebut merupakan bentuk kesantunan kepada orang lain dengan cara membagi perasaan yang sedang dialami, misalnya perasaan sedih ketika menghadapi kemalangan atau perasaan gembira ketika mereka bersukacita.

\section{METODE PENELITIAN}

Penelitian ini menggunakan metode penelitian deskriptif kualitatif. Penelitian deskriptif (descriptive research) ditujukan untuk mengeksplorasi dan mengklasifikasikan suatu fenomena atau kondisi sosial dengan cara mendeskripsikan variabel tertentu yang berkenaan dengan masalah yang dijadikan pertanyaan penelitiaan (Mulyadi, 2013: 132).

Pengumpulan data dalam penelitian ini menggunakan metode simak dengan teknik lanjutan yaitu tandai dan catat. Sumber data penelitian ini adalah komentar-komentar terhadap cuitan akun Twitter @cunggun yang bertema internalized sexism (Cunggun, 2019). Seksisme yang diinternalisasi (internalized sexism) merupakan suatu keadaan anggota suatu kaum yang menggunakan sesuatu yang dianggap kelemahan anggota kaumnya sendiri untuk menaikkan derajat dirinya dan 
menjatuhkan martabat atau nilai sesama anggota kaumnya yang lain. Misalnya, seorang wanita yang menggunakan kelemahan wanita lain untuk menaikkan nilainya sendiri di mata masyarakat. Kelemahan ini bersifat subjektif, artinya setiap kelemahan tidak selamanya dianggap sebagai kelemahan oleh pandangan seseorang. Seksisme ini melibatkan dua kelompok berbeda, yang satu secara sistematis ditolak kekuasaannya oleh yang lain, bukan hanya kelompok wanita. Internalized sexism melibatkan dinamika internal dalam suatu kelompok yang tertindas. Ini membantu untuk mempertahankan seksisme secara keseluruhan melalui sistem harapan dan tekanan sosial yang diberlakukan di kelompok tertentu (Bearman dkk., 2009).

Cuitan akun Twitter @cunggun diunggah pada 16 September 2019 dengan isi cuitan yaitu "cewe kalo dandan: pake alis, maskara, eye shadow, blushon, BB cream, cencelar. Gue: Bedak baby + liptint. TUHAN MENGAPA AKU BERBEDA? :")". Cuitan ini mendapat 1690 komentar, 2510 kali kiriman ulang, dan 9113 suka. Peneliti menyimak cuitan akun @cunggun dan komentar-komentar terhadap cuitan tersebut tanpa ikut menuliskan komentar. Kemudian, peneliti menandai dan mencatat kalimat-kalimat yang terindikasi melanggar prinsip kerja sama dan prinsip kesantunan berbahasa.

Data penelitian dianalisis menggunakan metode analisis isi (Sulistyowati, 2012). Data penelitian dikelompokkan berdasarkan prinsip kerja sama yang dibagi menjadi pelanggaran maksim kualitas, maksim kuantitas, maksim relevansi, dan maksim cara. Data penelitian juga dikelompokkan berdasarkan prinsip kesantunan berbahasa yang dibagi menjadi pelanggaran maksim kebijaksanaan, maksim kemurahan, maksim penerimaan, maksim kerendahan hati, maksim kecocokan, dan maksim kesimpatian. Penyajian hasil analisis data dilakukan secara deskriptif. Istilah penutur digunakan untuk menyebutkan pemilik cuitan bertema internalized sexism, yaitu akun @cunggun, sedangkan istilah petutur digunakan untuk menyebutkan penulis komentar-komentar terhadap cuitan dari akun @cunggun yang dijadikan sebagai sumber data penelitian. Kemudian, pembahasan atau analisis data dilakukan dengan menggunakan kode tertentu untuk menyebutkan contoh tuturan yang termasuk ke dalam pelanggaran prinsip kerja sama dan kesantunan bahasa. Kode KS-01, KS-02, KS-03, dst. digunakan untuk menyebut data dalam pelanggaran prinsip kerja sama. Adapun kode KB-01, KB-02, KB-03, dst. digunakan untuk menyebut data dalam pelanggaran prinsip kesantunan berbahasa.

\section{HASIL DAN PEMBAHASAN}

Berdasarkan penelitian yang telah dilakukan, berikut ini paparan mengenai pelanggaran prinsip kerja sama, pelanggaran prinsip kesantunan berbahasa, dan kemungkinan penyebab adanya pelanggaran prinsip kerja sama dan kesantunan berbahasa dalam komentar terhadap cuitan Twitter bertema internalized sexism.

\section{Pelanggaran Prinsip Kerja Sama \\ a. Maksim Kualitas}


KS-01 : "IYA LU BEDA SOALNYA GA MAMPU BELI PENSIL ALIS, BELI MASKARA, BELI EYE SHADOW, BELI BLUSH ON, BELI BB CREAM, BELI CONCELAR ALIAS LU MISKIN ANJINK."

Data tuturan KS-01 menunjukkan adanya pelanggaran maksim kualitas karena petutur tidak memberi kontribusi sesuai dengan yang diminta oleh penutur, yaitu akun Twitter @cunggun. Petutur dengan tegas menyebut bahwa penutur tidak mampu membeli beragam jenis makeup. Petutur juga menganggap penutur adalah orang miskin. Pada akhir tuturan, disertakan pula makian anjink (anjing) sebagai bentuk kekesalan petutur terhadap cuitan penutur. Berdasarkan penjelasan tersebut, petutur sebenarnya kekurangan bukti yang memadai perihal alasan sebenarnya penutur tidak berdandan seperti wanita kebanyakan. Dalam komunikasi tulisan, terutama pada media sosial, penggunaan huruf kapital digunakan sebagai penanda kemarahan, penegasan, atau rasa kesal. Penggunaan huruf kapital pada keseluruhan kalimat tuturan data KS-01 menyiratkan adanya kemarahan atau kekesalah petutur yang disebabkan oleh cuitan akun @cunggun. Jika petutur menuliskan komentarnya sesuai dengan maksim kualitas dalam prinsip kerja sama, maka komentar tersebut akan ditulis "soalnya ga mampu beli pensil alis, beli maskara, beli eye shadow, beli blush on, beli concelar" atau "karena lu miskin". Hal ini disebabkan karena penggunaan partikel karena atau soalnya (dalam bahasa gaul) merupakan penanda jawaban dari pertanyaan mengapa. Sayangnya, petutur dalam komentarnya mencantumkan informasi berlebih yang belum tentu kebenarannya, sehingga kalimat komentar dari petutur ini tidak akan dikategorikan sebagai pelanggaran maksim kualitas.

\section{KS-02 : "Iya lu beda soalnya lu jelek kan."}

Data tuturan KS-02 termasuk ke dalam pelanggaran maksim kualitas karena petutur tidak berkontribusi sesuai dengan yang diinginkan oleh penutur cuitan. Selain itu, petutur juga kekurangan bukti perihal jelek tidaknya penutur cuitan. Partikel penegas kan pada akhir tuturan digunakan untuk mencari kebenaran informasi sesuai dengan interpretasi petutur. Namun, komentar ini tidak mendapat tanggapan dari penutur cuitan. Maka dari itu, kebenaran informasi mengenai jeleknya rupa penutur diragukan. Jika penutur @cunggun menanggapi kalimat pada data KS-02, misalnya dengan jawaban " $y a^{\prime}$, data ini tidak akan dikategorikan sebagai pelanggaran maksim kualitas. Selain itu, jika kalimat komentar pada data KS-02 ditulis "soalnya lu jelek", data ini tidak akan dikategorikan sebagai pelanggaran maksim kualitas karena adanya penggunaan partikel soalnya sebagai jawaban dari pertanyaan mengapa yang diajukan oleh pemilik akun @cunggun.

\section{b. Maksim Kuantitas}

KS-03 : "Iya lu doang diciptain buluk, kami cantik."

Data tuturan KS-03 melanggar maksim kuantitas karena petutur memberi informasi yang berlebih dari yang diminta oleh penutur. Penanda informasi berlebih ini adalah frasa kami cantik. Penutur cuitan bertanya "mengapa aku berbeda?". Petutur sebenarnya cukup menjawab atau berkomentar "Iya lu doang diciptain buluk". Melalui 
kalimat tersebut, pertanyaan penutur telah terjawab, meskipun jawaban yang didapatkan merupakan suatu penghinaan. Namun, penambahan informasi "kami cantik" setelah kalimat "Iya lu doang diciptain buluk" menjadikan kontribusi informasi dalam tuturan data KS-03 lebih informatif daripada yang dibutuhkan oleh penutur cuitan. Berdasarkan data ini, dapat dilihat bahwa kalimat sindiran cenderung memberikan informasi yang berlebihan dan tidak diperlukan dengan tujuan untuk melemahkan tuturan penutur.

\section{c. Maksim Relevansi}

\section{KS-04 : "Ternyata di dunia ini emg ada org yg minta dihujat"}

Data KS-04 menunjukkan tidak adanya relevansi antara tanggapan petutur dengan situasi tuturan. Penutur cuitan membutuhkan jawaban berupa alasan melalui penanda kata tanya mengapa yang jawabannya biasanya diawali dengan partikel karena, sebab, sebabnya, atau dalam bahasa gaul digunakan partikel soalnya. Namun, data KS-04 sama sekali tidak menunjukkan adanya kontribusi informasi dari petutur untuk penutur cuitan. Hal ini menjadikan data KS-04 termasuk ke dalam pelanggaran maksim relevansi. Jika diselidik dari segi makna tuturan, petutur merasa kesal hingga menyindir penutur. Namun, tetap saja hal ini tidak menjadi pembenaran dalam prinsip kerja sama. Apapun yang dirasakan petutur terhadap tuturan penutur, hendaknya informasi yang diberikan sesuai dan relevan dengan situasi tuturan yang sedang berlangsung, serta tidak dimaksudkan untuk menyudutkan penutur.

\section{KS-05 : "Bedak bayi bukannya untuk pantat bayi?"}

Data KS-05 tidak menunjukkan adanya relevansi informasi yang diberikan oleh petutur dengan situasi tuturan yang sedang terjadi. Petutur malah memberikan pertanyaan, bukannya memberikan jawaban terhadap pertanyaan penutur cuitan. Walaupun petutur menyebutkan frasa bedak bayi, yang secara teknis memang disebutkan pula oleh penutur cuitan, tetapi hal ini tidak menjadikan data KS-05 tidak melanggar maksim relevansi dalam prinsip kerja sama. Data KS-05 tidak akan dikategorikan sebagai pelanggaran maksim relevansi jika kalimatnya berbunyi " gak apa-apa pakai bedak bayi + liptint. Setiap manusia kan berbeda". Penggunaan kalimat ini masih memiliki relevansi dengan isi cuitan penutur, tetapi petutur tidak memilih untuk menjadikan kalimat jawabannya berkorelasi dengan cuitan penutur.

\section{d. Maksim Cara}

\section{KS-06 : "Semoga abadi mbak cantik natural."}

Data KS-06 menunjukkan adanya pelanggaran maksim cara karena petutur tidak bersikap dengan jelas jika disesuaikan dengan situasi tuturan yang sedang berlangsung. Harapan yang dituturkan oleh petutur tidak menjelaskan secara gamblang perihal sikap petutur terhadap cuitan penutur. Kontribusi informasi pada 
data KS-06 dari petutur tidak dibutuhkan dalam situasi tuturan yang sedang berlangsung. Beberapa kiat dalam maksim cara adalah bersikap singkat dan hindari kecurangan yang tidak perlu. Data tuturan KS-06 sudah menunjukkan sikap yang singkat, tetapi curang. Kecurangan yang tidak perlu dalam data ini adalah harapan yang ditandai adverbia semoga merupakan harapan palsu berupa ironi. Hal ini disebabkan karena adanya penanda berupa frasa "mbak cantik natural". Petutur data ini menyimpulkan pemilik akun @cunggun sebagai wanita yang memiliki kecantikan natural, sehingga keadaan ini perlu didoakan keabadiannya. Jika petutur menuliskan kalimat komentarnya dengan bunyi "semua orang memang beda", data KS06 tidak akan dikategorikan sebagai pelanggaran maksim cara karena petutur sudah bersikap singkat dan tidak melakukan kecurangan pada kalimat tersebut.

\section{Pelanggaran Prinsip Kesantunan Berbahasa \\ a. Maksim Kebijaksanaan}

KB-01 : "Apaan sih lebay bener."

Data KB-01 menunjukkan adanya pelanggaran karena petutur merendahkan penutur dengan penggunaan frasa lebay bener. Dalam kultur keseharian masyarakat Indonesia, lebay identik dengan suatu hal yang berlebihan dan memiliki tendensi makna yang negatif. Artinya, petutur dalam situasi tuturan ini malah memaksimalkan kerugian bagi penutur cuitan. Jika pengguna Twitter lainnya membaca data KB-01 dalam komentar terhadap cuitan akun @cunggun, orang bisa ikut berpikiran bahwa penutur cuitan bersikap lebay. Hal ini akan mengakibatkan adanya kerugian bagi penutur, yaitu ikut dipandang sebagai orang yang lebay. Keadaan ini tentu tidak sejalan dengan maksim kebijaksanaan yang menuntut agar penutur atau petutur meminimalkan kerugian orang lain atau memaksimalkan keuntungan orang lain. Agar tidak dikategorikan sebagai pelanggaran maksim kebijaksanaan, kalimat komentar pada data KB-01 dapat ditulis "gak apa-apa beda, kamu tetap cantik, kok". Dalam kalimat ini, petutur telah memaksimalkan keuntungan orang lain (akun @cunggun) melalui ungkapan kamu tetap cantik. Namun, alih-alih menggunakan kalimat seperti contoh tersebut, petutur memilih untuk menuliskan "apaan sih lebay bener".

\section{KB-02 : "Iya iya lu natural dah anjing"}

Pelanggaran maksim kebijaksanaan pada data KB-02 disebabkan karena petutur memaksimalkan kerugian orang lain, yang dalam hal ini adalah penutur cuitan. Seharusnya, petutur bisa lebih bijaksana dalam pemilihan kalimat dalam komentarnya terhadap cuitan penutur. Namun, terdapat makian anjing yang diletakkan di akhir kalimat. Selain itu, pengulangan kata iya sebanyak dua kali juga dapat diartikan sebagai ejekan. Hal ini menandakan tidak adanya kebijaksanaan dalam pemilihan kata untuk meminimalisasi kemungkinan orang lain merasa tersakiti. Jika kata iya hanya disebutkan satu kali dan interjeksi dah serta makian anjing dihilangkan dalam data KB-02 menjadi "iya lu natural", data ini tidak akan dikategorikan sebagai pelanggaran maksim kebijaksanaan. 
Pelanggaran Prinsip Kerja Sama dan Kesantunan Berbahasa dalam Cuitan Twitter Bertema Internalized Sexism 'Internalisasi Seksisme': Suatu Kajian Pragmatik

\title{
b. Maksim Kemurahan
}

\author{
KB-03 : "Mengapa aku berbeda, mengapa aku berbeda, BACOT. GA LU DOANG \\ YANG BEDA. GA LU DOANG YANG KEK GINI, MANUSIA DI \\ DUNIA ADA TRILIUNAN. GOSAH MERASA SPESIAL SATU \\ SATUNYA KEK FRANDA TOLONG."
}

Data KB-03 melanggar maksim kemurahan karena tidak meminimalisasi terjadinya kemungkinan orang lain merasa tersinggung terhadap tuturan ini. Penggunaan kata bacot sebagai makian dan penulisan komentar yang didominasi huruf kapital menandakan adanya kemarahan yang dirasakan oleh petutur. Namun, kemarahan tidak bisa menjadi pembenaran agar tuturan bisa dilakukan sesuka hati tanpa memperhatikan adanya kemungkinan pihak lain merasa tersinggung. Pengulangan kalimat tanya "mengapa aku berbeda, mengapa aku berbeda" merupakan ejekan yang diperkuat melalui kata BACOT di akhir kalimat. Kata bacot sendiri dalam percakapan sehari-hari digunakan sebagai makian dan interjeksi kekesalan atau kemarahan. Maksim ini mengharapkan penutur agar menggunakan kalimat yang sopan. Namun, tidak nampak adanya kesopanan pada data ini. Selain itu, tidak ada kontribusi informasi yang dibutuhkan penutur dalam tuturan KB-03. Sesuai dengan prinsip kesopanan, data KB-03 sama sekali tidak mencerminkan kesantunan berbahasa. Kalimat data KB-01 jika hanya ditulis menjadi "ga lu doang yang beda", maka tidak akan dikategorikan sebagai pelanggaran maksim kemurahan.

\section{c. Pelanggaran Maksim Pujian}

KB-04 : "Emang beda kalo udah tjakep si. Beda ama yg buriq kudu di dempul yg maxsimal biar tjakepan."

Data tuturan KB-04 menunjukkan adanya pelanggaran maksim pujian. Data ini tidak menunjukkan adanya pemaksimalan penghormatan, tetapi malah memaksimalkan ketidakhormatan melalui pemilihan kalimat komentar dalam bentuk sindiran. Penanda pemaksimalan ketidakhormatan ini terletak pada kalimat "emang beda kalo udah tjakep si". Melalui kalimat tersebut, tuturan KB-04 terlihat memuji pemilik akun @cunggun yang dianggapnya sudah cantik. Namun, kata cakep yang ditulis tjakep pada media sosial biasanya digunakan sebagai salah satu sindiran atau pujian bohong. Maka, penutur data ini beranggapan bahwa pemilik akun @cunggun sudah cantik sehingga tidak memerlukan beragam jenis makeup dan membandingkannya dengan orang lain yang dianggap tidak cantik (burik) sehingga harus memakai makeup. Namun, jika melihat pada situasi tuturan dalam komentar terhadap cuitan akun @cunggun, maka data KB-04 bukan merupakan pujian, melainkan sindiran terhadap cuitan akun @cunggun. Salah satu alternatif penulisan kalimat komentar sesuai dengan maksim pujian yang dapat ditulis oleh petutur adalah "emang beda kalo udah cakep". Melalui kalimat ini, petutur telah memaksimalkan penghormatan dan pujian terhadap pemilik akun @cunggun. 
KB-05 : "Asik cantiknya alami dong ya? Natural? Woowwww jadi taneman aja mba."

Data tuturan KB-05 merupakan bentuk sindiran terhadap cuitan akun @cunggun. Terdapat pujian dalam data ini melalu kalimat tanya yang diawali kata asik, yaitu "asik, cantiknya alami dong ya?". Penggunaan partikel dong pada kalimat ini berfungsi sebagai pemanis atau pelembut kalimat. Selain itu, pujian juga ditandai oleh penggunaan interjeksi wow, meskipun kalimat imperatif selanjutnya berupa sindiran. Sindiran ditandai dengan pernyataan "... jadi taneman aja mba". Kalimat tanya pada data ini menunjukkan pujian, yaitu pertanyaan penegas petutur karena menganggap penutur memiliki kecantikan yang alami. Namun, pujian ini merupakan bentuk pujian semu. Di akhir tuturan, petutur malah menyuruh pemilik akun@cunggun supaya menjadi tanaman karena kecantikannya yang natural. Alternatif untuk menghindari kalimat pada data KB-05 dikategorikan sebagai pelanggaran maksim pujian adalah cukup dengan menulis "asik, cantiknya alami". Jika kalimat ini digunakan, petutur telah memaksimalkan penghormatan dan pujiannya untuk pemilik akun @cunggun.

\section{d. Maksim Kerendahan Hati}

KB-06 : "Kalo di kantorku kamu pasti dipecat. Kena SP 1."

Data KB-06 menunjukkan adanya pelanggaran maksim kerendahan hati. Hal ini disebabkan karena petutur meremehkan penutur cuitan dengan mengibaratkan jika pemilik akun @cunggun sebagai pegawai di kantornya, maka akan mendapat surat peringatan karena tidak bisa berdandan. Penyebutan "kantorku" mengindikasikan adanya kesombongan melalui penyebutan persyaratan pegawai kantornya yang disebutkan secara tersirat. Selain itu, kalimat "kamu pasti dipecat" menunjukkan adanya keyakinan pemilik akun akan benar-benar dipecat karena tidak berdandan menggunakan alat berdandan yang lengkap. Kesombongan ini baru berupa premis atau pengandaian, tetapi petutur terlihat yakin premis ini akan terjadi. Maka dari itu, tuturan data KB-01 dikategorikan sebagai pelanggaran maksim kerendahan hati. Jika petutur menggunakan kalimat "untung kamu gak kerja di kantorku karena di sana harus bisa dandan, maka kalimat ini tidak akan dikategorikan sebagai pelanggaran maksim kerendahan hati.

\section{e. Maksim Kecocokan}

KB-07 : "Karna lu miskin beb makanya gabisa beli make up hehehehe."

Data KB-07 menunjukkan adanya pelanggaran maksim kecocokan. Hal ini disebabkan karena adanya unsur penghinaan yang menunjukkan perbedaan posisi petutur dengan penutur cuitan. Walaupun kontribusi informasi dalam data KB-07 sesuai dengan situasi tuturan yang diinginkan penutur cuitan, yaitu jawaban dengan partikel "karena" terhadap pertanyaan "mengapa", tetapi maksim kecocokan tidak hadir dalam tuturan ini. Petutur menyebutkan kata miskin sebagai sebab ketidakmampuan penutur menggunakan beragam jenis makeup. Pada data ini, kata 
miskin bertendensi negatif yang menyiratkan ketidakcocokan petutur dengan penutur cuitan yang dikemukakan secara tidak bijak. Selain itu, penutur data KB-07 menunjukkan perbedaan derajat sosial antara dirinya dan pemilik akun @cunggun melalui penggunaan kata hehehehe yang bermakna ejekan. Sebenarnya, data KB-07 tidak akan dikategorikan sebagai pelanggaran maksim kecocokan jika komentarnya hanya ditulis "karena lu miskin beb", karena sudah sesuai atau cocok dengan tuturan yang dituturkan oleh pemilik akun @cunggun.

\section{KB-08 : "Kamunya aja miskin gabisa beli."}

Data KB-08 memiliki tipe yang sama dengan data KB-07. Penyebutan kata miskin dalam data ini juga bertendensi negatif. Tuturan data KB-08 berkemungkinan memaksimalkan adanya kesalahpahaman dalam situasi tuturan yang sedang berlangsung. Jika tidak ingin dikategorikan sebagai pelanggaran maksim kecocokan, salah satu alternatif penulisan kalimat untuk data KB-08 adalah "karena gak bisa beli make up". Melalui kalimat ini, petutur sudah berkontribusi sesuai atau cocok dengan yang diinginkan oleh penutur cuitan pada sumber data penelitian.

\section{f. Pelanggaran Maksim Kesimpatian}

\section{KB-09 : "Bodoamat anjing mau bedak bayi liptint doang situ superior?"}

Data KB-09 tidak menunjukkan adanya rasa simpati yang dirasakan oleh petutur terhadap cuitan akun @cunggun. Pelanggaran maksim kesimpatian ini ditunjukkan oleh penggunaan ungkapan bodo amat dan makian anjing dalam tuturan. Petutur tidak merasa simpati atas perasaan sedih yang dirasakan oleh penutur cuitan, yaitu@cunggun. Data KB-09 memaksimalkan kemungkinan terjadinya ketidakharmonisan dalam situasi tuturan yang sedang berlangsung. Selain itu, frasa "situ superior?" juga menunjukkan bahwa penutur data KB-09 tidak memiliki keprihatinan emosional. Frasa tersebut justru menyerang dan memojokkan pemilik akun @cunggun. Jika kalimat pada data KB-09 cukup ditulis "gak apa-apa pakai bedak bayi dan liptint doang", kalimat ini tidak akan dikategorikan sebagai pelanggaran maksim kesimpatian karena tidak menimbulkan ketidakharmonisan dalam situasi tuturan.

\section{Kemungkinan Penyebab Pelanggaran Prinsip Kerja Sama dan Prinsip Kesantunan Berbahasa dalam Komentar Terhadap Cuitan Twitter Bertema Internalized Sexism}

Latar belakang budaya yang disoroti dalam penelitian ini adalah budaya penggunaan kosmetik serta pandangan masyarakat terhadap keadaan tersebut. Penggunaan kosmetik sudah dilakukan sejak zaman dahulu. Kosmetik erat kaitannya dengan wanita dan sifat feminin yang dimilikinya. Kosmetik dianggap sebagai penunjang penampilan. Artinya, penampilan yang rapi dan segar bisa diciptakan dengan padu padan pakaian serta penggunaan riasan wajah yang tepat sesuai situasi yang dihadiri. Sayangnya pada beberapa keadaan, wanita memiliki 
posisi yang kurang menguntungkan karena stigma masyarakat yang lebih berpihak pada wanita yang dianggap cantik dan abai terhadap wanita yang dianggap bermuka biasa atau standar. Kemudian, hadir anggapan bahwa riasan hanya berfungsi sebagai topeng penutup wajah asli seseorang. Para wanita yang menggunakan riasan untuk mempercantik diri malah dianggap palsu dan menipu. Keadaan ini pada akhirnya yang menjadikan internalized sexism menjadi marak terjadi di masyarakat, tetapi hal ini umumnya terjadi dengan tanpa disadari para pelakunya. Jika terdapat istilah women support women, maka terdapat standar ganda terhadap istilah tersebut. Pada satu sisi, wanita menginkan kesetaraan, penghormatan, dan apresiasi yang layak dari sesama maupun lawan jenisnya. Namun di sisi yang lain, secara tidak disadari wanita malah menjatuhkan sesamanya hanya agar dirinya bisa terlihat berbeda dan memiliki nilai lebih dibanding dengan kaumnya.

Internalized sexism merupakan fenomena sosial sebagai hasil dari persaingan antarsesama wanita untuk mendapat perhatian dari sesama atau lawan jenisnya. Sayangnya, proses ini dirasa salah karena wanita terkesan menjadi "musuh dalam selimut". Wanita menjadi perusak kaumnya dan tidak menghargai hal yang disukai oleh orang lain. Seseorang yang merias dirinya merupakan salah satu pemenuhan hak individu dalam bentuk estetika. Sudah sepatutnya pihak lain tidak menganggap hal ini sebagai sesuatu yang negatif dan dijadikan kelemahan untuk menyerang sesamanya hanya agar dirinya menjadi terlihat lebih baik dan memiliki nilai lebih dibanding dengan yang lainnya.

Keadaan ini bisa dilihat pada cuitan Twitter akun @cunggun. Cuitan tersebut membuat pernyataan bahwa wanita kebanyakan berias menggunakan alis, maskara, eye shadow, blushon, BB cream, dan concelar, sedangkan pemilik akun hanya menggunakan bedak bayi ditambah liptint. Secara tidak langsung, pemilik akun menjatuhkan "nilai" yang dimiliki oleh wanita berias dengan cara membuat dirinya terlihat berbeda dan sederhana tetapi tetap terlihat cantik. Selain itu, kalimat pertanyaan "TUHAN MENGAPA AKU BERBEDA?:"" mengindikasikan bahwa pemilik akun merasa istimewa karena perbedaan yang ada. Penggunaan tanda:") dalam percakapan media sosial mewakili ekspresi tangis yang ditahan, tetapi sering pula diartikan sebagai ekspresi pura-pura sedih. Akun @cunggun menggunakan tanda tersebut untuk mengindikasikan bahwa dia merasa sedih karena tidak berias dengan menggunakan alat kosmetik yang beraneka ragam. Namun lebih dari itu, kalimat interogatif yang seluruhnya ditulis dengan huruf kapital dan dibubuhi tanda tertentu sebagai pendamping kanan menjelaskan bahwa pemilik akun dianggap mencari perhatian oleh warganet.

Kemarahan dan kekesalan warganet ini menjadikan mereka menulis beragam komentar kontra menggunakan bahasa yang kurang sopan. Sayangnya, komentar-komentar ini melanggar maksim-maksim dalam prinsip kerja sama dan kesantunan berbahasa. Pelanggaran maksim kerja sama dan kesantunan berbahasa merupakan salah satu penyebab maraknya kesalahpahaman dan pertengkaran atau konflik yang terjadi dalam media sosial. Kebebasan bermedia sosial menjadikan masyarakat kurang memiliki kepekaan untuk menjaga hubungan baik antara dirinya dan orang lain. 


\section{PENUTUP}

Kesantunan berbahasa dalam komentar terhadap cuitan akun @cunggun bertema internalized sexism. Pelanggaran prinsip kerja sama dan prinsip kesantunan berbahasa dibagi menjadi pelanggaran maksim-maksim tertentu. Pelanggaran prinsip kerja sama terjadi pada (1) maksim kualitas; (2) maksim kuantitas; (3) maksim relevansi; dan (4) maksim cara. Kemudian, pelanggaran prinsip kesantunan berbahasa terjadi pada (1) maksim kebijaksanaan; (2) maksim kemurahan; (3) maksim penerimaan; (4) maksim kerendahan hati; (5) maksim kecocokan; dan (6) maksim kesimpatian. Kemungkinan penyebab terjadinya pelanggaran prinsip kerja sama dan prinsip kesantunan berbahasa ini antara lain karena dilakukan secara sengaja sebagai kritik langsung dengan penggunaan kata-kata kasar (makian anjing dan bacot) dan dorongan rasa emosi petutur terhadap cuitan @cunggun karena pemilik akun tersebut melakukan praktik internalized sexism.

Penelitian mengenai pelanggaran prinsip kerja sama dan prinsip kesantunan berbahasa masih bisa dilakukan karena sumber data untuk penelitian ini sangat luas. Semua situasi yang menggunakan bahasa, baik bahasa tulis dan bahasa lisan, maupun bahasa komunikasi langsung dan bahasa media sosial, bisa dijadikan sebagai sumber data penelitian. Penelitian mengenai pelanggaran prinsip kerja sama dan prinsip kesantunan berbahasa perlu dilakukan agar masyarakat mampu meminimalisasi kemungkinan terjadinya kesalahpahaman berujung pertikaian yang disebabkan oleh pelanggaran maksim-maksim dalam prinsip kerja sama dan kesantunan berbahasa.

\section{DAFTAR PUSTAKA}

Adani, R., Rahmat, N., \& Sunarni, N. (2017). Strategi Kesantunan Tuturan Ketidaksetujuan dalam Drama 101St Marriage Proposal. Metahumaniora, 7(1), 82-90. https:/ / doi.org/10.24198/mh.v7i1.23330

Bachari, A. D., \& Juansah, D. E. (2017). Pragmatik (Analisis Penggunaan Bahasa). Bandung: Prodi Linguistik SPs UPI.

Bearman, S., Korobov, N., \& Thorne, A. (2009). The Fabric of Internalized Sexism. Journal of Integrated Social Sciences, 1(1), 10-47.

Budiawati, T. R. (2017). Kesantunan Berbahasa Mahasiswa dalam Berinteraksi dengan Dosen di Universitas Ahmad Dahlan: Analisis Pragmatik Abstrak. The 5Th Urecol Proceeding, February, 557-571.

Chaer, A. (2010). Kesantunan Berbahasa. Jakarta: Rineka Cipta.

Cunggun.

Status.

https://twitter.com/cunggun/status/1173431805979971584 pada 16 Juni 2020.

Halawa, N., Gani, E., \& R, S. (2019). Kesantunan Berbahasa Indonesia dalam Tindak Tutur Melarang dan Mengkritik pada Tujuh Etni. Lingua: Jurnal Bahasa, Sastra, dan Pengajarannya, 15(2), 195-205.

Kroeger, P. R. (2018). Analyzing Meaning an Introduction to Semantics and Pragmatics (Textbooks in Language Science 5). Berlin: Language Science Press. https://doi.org/10.5281/zenodo.1164112

Leech, G. (2014). The Pragmatics of Politeness. New York: Oxford University Press. 
Mulyadi, M. (2013). Penelitian Kuantitatif dan Kualitatif serta Pemikiran Dasar Menggabungkannya. Jurnal Studi Komunikasi dan Media, 15(1), 127-138. https://doi.org/10.31445/jskm.2011.150106

Pramujiono, A. (2015). Representasi Kesantunan Positif-Negatif Brown dan Levinson dalam Wacana Dialog di Televisi. Bahastra, 33(2), 43-72. https://doi.org/10.26555/bahastra.v33i2.2717

Sari, E. S. (2019). Pelanggaran Prinsip Kesantunan dalam Acara Dua Arah Kompas TV. Sapala, 1(1), 1-10. https:/ /jurnalmahasiswa.unesa.ac.id/index.php/jurnalsapala/article/view/22840

Sekarsany, A., Darmayanti, N., \& Suparman, T. (2020). Tindak Tutur Ilokusi pada Proses Kelahiran dengan Teknik Hipnosis (Hypnobirthing). Metahumaniora, 10(1), 14-26. https://doi.org/10.24198/mh.v10i1.26607

Sulistyowati, W. (2012). Pelanggaran Prinsip Kerja Sama dan Implikatur Percakapan dalam Film Petualangan Sherina Karya Riri Riza. Skriptorium, 2(2), 126-134. http:/ /journal.unair.ac.id/downloadfull/SKRIPTORIUM7842a6ace2d174fulla bstract.pdf

Tiarina, Y. (2012). Prinsip Kerjasama dalam Film Kartun Avatar. Komposisi: Jurnal Pendidikan Bahasa, Sastra, dan Seni, 11(1), 1-9. https:/ / doi.org/10.24036/komposisi.v11i1.77 